
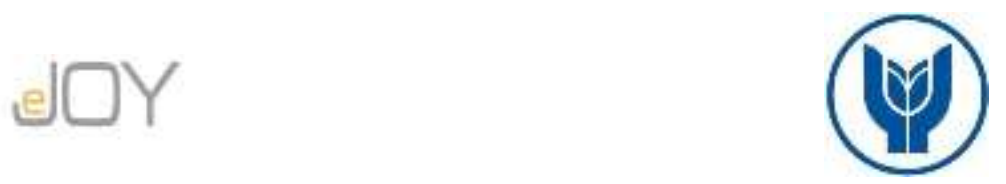

Day1, F., Esmer, Y. / Journal of Yasar University, 2021, 16/61, 1-19

\title{
Akademisyenlerin Finansal Tutum ve Davranışlarının İncelenmesine Yönelik Bir Araştırma
}

\section{A Study on The Financial Attitudes and Behaviors of Academicians}

\author{
Faruk DAYI, Kastamonu Üniversitesi, Türkiye, fdayi@kastamonu.edu.tr \\ Orcid No: 0000-0003-0903-1500 \\ Yusuf ESMER, Bayburt Üniversitesi, Türkiye, yesmer@bayburt.edu.tr \\ Orcid No: 0000-0003-3691-1730
}

\begin{abstract}
Öz: Finansal tutum ve davranışlar, bireylerin finansal konulardaki eğilimlerini gösteren davranışlardır. Bireylerin finansal bilgi düzeyinin finansal tutum ve davranışlarına yansıdığ d düşünülmektedir. Bu bağlamda akademisyenlerin finansal tutum ve davranışlarında daha dengeli davranmalarl beklenmektedir. Bu temel yargıdan hareketle bu çalışmada akademisyenlerin finansal tutum ve davranışları (harcama, tutum ve ilgi) demografik değişkenler bakımından incelenmiştir. Bu amaç doğrultusunda nicel araştırma kapsamında anket tekniği kullanılarak Türkiye`de Karadeniz Bölgesi ndeki tüm üniversitelerde görev yapan 405 akademisyenden veri toplanmıştır. Toplanan veriler SPSS 22.0 programında çeşitli analizlere tabi tutulmuştur. Analiz sonucunda; akademisyenlerin finansal tutum ve davranışlarında cinsiyet, yaş ve medeni durum gibi demografik değişkenler açısından kısmen anlamlı bir farklılığın olduğu, unvan ve aylık gelir demografik değişkenleri açısından anlamlı bir farklılı̆̆ın olmadı̆̆ tespit edilmiştir.
\end{abstract}

Anahtar Sözcükler: Finansal Tutum, Finansal Davranış, Davranışsal Finans, Akademisyenler

JEL Sinıflandirması: D23, G02, M10

Abstract: Financial attitudes and behaviors indicate the tendencies of individuals on financial issues. It is thought that the financial information level of individuals is reflected in financial attitude and behaviors of individuals. In this context, it is expected that academicians should behave more balanced in their financial attitudes and behaviors. From this point of view, financial attitude and behaviors of academicians (expenditure, attitude and interest) were examined in terms of demographic variables in this study. For this purpose data was collected from 405 academicians who work in all universities in Black Sea Region of Turkey by using the survey technique of quantitative research. The data collected were subjected to various analyzes in SPSS 22.0 program. As a result of the analysis; there was a significant difference in financial attitudes and behaviors in terms of demographic variables such as gender, age and marital status and it was determined that there was no significant difference in demographic variables such as title and monthly income.

Keywords:Financial Attitudes, Financial Behaviors, Behavioral Finance, Academicians

JEL Classification: D23, G02, M10

\section{Giriş}

Son yıllarda finansal okuryazarlık konusunda birçok çalışma yapılmıştır. Özellikle ön lisans ve lisans düzeyinde öğrenim gören üniversite öğrencilerinin finans dersleriyle ilgili temel bilgi düzeyinin ölçülmesine yönelik anketlerin geliştirildiği görülmektedir. Çalışmaların çoğunda öğrencilerin finansal okuryazarlık ile temel bilgi düzeylerinin ölçüldüğü tespit edilmiştir. Bazı çalışmalarda ise finansal tutum ve davranışların ölçülmesine yönelik soruların sorulduğu ancak çalışmaların tümü içinde finansal tutum ve davranışlarla ilgili genel bir 
yargıya varılmadığı belirlenmiştir. Bu nedenle tüketim çağında yaşayan bireylerin sadece finansal okuryazarlık düzeyini ölçmektense, günümüz koşullarında finansal kararları alırken izlediği tutum ve davranışların boyutunu değerlendirmek bireylerin kendi finansal kararlarında nasıl bir tutum izlediğini keşfederek, tasarrufu artırıcı hangi politikaların uygulanması gerektiğini anlamak için önem arz etmektedir.

Gelirdeki artışın tüketim alışkanlıklarını değiştirebileceği düşünülmektedir. Çünkü günümüz ekonomisi, üretim toplumundan daha çok tüketim toplumuna doğru bir eğilim sergilemektedir. Bireyler teknolojideki gelişmelere bağlı olarak nakit ödemeler dışında kredi kartı gibi farklı ödeme araçlarını da kullanabilmektedir. Ödeme araçlarındaki çeşitlilik, bireylere esneklik ve zaman kazandırmakta ve tüketimin artmasında etkili olmaktadır. Kredi kartlarındaki artışın finansal tutum ve davranışlar üzerinde önemli bir etkisi olduğu gözlemlenmiştir (Denk vd., 2018, 187). Bireyler yatırım yapmaktansa ihtiyaçlarını karşılamaya diğer bir ifadeyle tüketime daha çok önem vermektedir. Tüketimin artmasıyla tasarrufların toplam gelir içindeki payında önemli oranlarda azalış görülmektedir. Bireylerin tasarruf yapmamaları, üretim miktarı sabitken tüketimin artmasına, fiyatların yükselmesine ve tüketimin artmasından dolayı doğadaki kıt kaynakların azalmasına neden olabilmektedir. $\mathrm{Bu}$ nedenle bireyler tüketim alışkanlıklarında daha bilinçli ve optimum davranmaları gerekmektedir. Çünkü tüketim harcamalarıyla sadece günlük ihtiyaçların karşılanması değil, menkul ve gayrimenkul varlıkların alımını da içermektedir. Bireylerin gelir gider dengesini sağlayamaması, borçlanma eğilimi ve borçların ödenmemesi finansal sistemdeki istikrarın bozulmasına neden olmaktadır. Finansal sistemin bozulması, finansal kararlardaki isabetsizlik, geçmiş yıllarda ekonomik ve finansal krizlerin çıkmasının önemli nedenlerinden biridir (Çoşkun, 2016, 2248).

Finansal krizlerin olduğu dönemlerde, bireyler ihtiyatlı davranarak tüketim harcamalarını kısmakta, tasarruflar artırılmakta ve ekonominin büyümesiyle birlikte bireyler daha fazla tüketim harcaması yaparak ekonominin canlanmasına katkı sağlayacak finansal tutum ve davranış sergiledikleri görülmektedir (Er ve Çetintaş, 2018, 62). Finansal krizlerin bireylerin finansal tutum ve davranışları üzerinde olumlu etkilerinin yanında olumsuz etkileri de mümkündür. Örneğin, 2008 yllında Amerika Birleşik Devletlerinde başlayan Mortage Krizinde, faiz oranındaki artış bireylerin ödeme gücünü düşürmüş, bireylerin aldıkları kararlarda yanılmalarına neden olmuştur (Er ve Çetintaş, 2018, 69). Finansal tutum ve davranışlarında optimal ve rasyonel davranılmaması bireylerin yanlış yatırım kararları sonucunda ekonomik kayıplara neden olabilmektedir. Toplumun temelinde bu eğilimin görülmesi ekonominin olumsuz etkilenmesine neden olmaktadır. Bu nedenle bu çalışmada 
bireylerin finansal tutum ve davranışlarının önemi teorik olarak vurgulanarak iktisadi ve idari bilimler alanında çalışan akademisyenlerin finansal tutum ve davranışları demografik özellikler açısından incelenmiştir. Bireylerin finansal konularda bilgi sahibi olmaları finansal tutum ve davranışlarını etkilediği düşünülmektedir. Bu bağlamda çalışmanın uygulaması finansal tutum ve davranışlarında daha bilinçli ve ihtiyatlı oldukları varsayılan akademisyenler üzerinde yapılmaktadır. Bu nedenle akademisyenlerin finansal tutum ve davranışlarının incelenmesinin literatüre katkı sağlaması beklenmektedir.

\section{Literatür}

$\mathrm{Bu}$ bölümün ilk kısmında finansal tutum ve davranış kavramları kısaca açıklanmaktadır. İkinci ve son kısımda ise finansal tutum ve davranışlar ile ilgili literatürde yer alan çalışmalara değinilmiştir.

\subsection{Finansal Tutum ve Davranışlar}

Allport (1935), tutum kavramının sosyal psikolojide çok uzun zamandır kabul edilen önemli bir kavram olduğunu ifade etmektedir. Tutum, bireylerin belirli nesneler veya davranışlar üzerinde sergilediği olumlu veya olumsuz davranışlar olarak tanımlamak mümkündür (Kroesen vd., 2017, 190). Tutum, belirli olaylara karşı önceden yaşanmış deneyimler sonucunda alınan tavırdır (Özkalp vd. 2013, 69). Yapılan araştırmalar tutumların, davranışlar üzerinde güçlü bir etkiye sahip olduğunu göstermektedir (Glasman ve Dolores, 2006, 778). Çünkü tutum bireylerin yaşamlarından elde ettikleri bilgi ve tecrübeler sonucunda oluşmakta, bireylerin birbirlerinden farklılı̆̆ını ortaya koymaktadır (Özkalp vd., 2013, 69). Tutum ve davranışların değişmesinde eğitim önemli bir faktör olarak görülmektedir (Taştan vd., 2001, 169). Bireylerin finansal olaylarda olumlu finansal tutum ve davranış gösterebilmeleri için finansal bilgiye sahip olmaları gerekmektedir.Finansal eğitimin finansal bilgi düzeyini pozitif yönde etkilemesinden dolayı, bilgi düzeyindeki artış finansal tutum ve davranışlara olumlu etki etmektedir (Yong vd., 2018, 21).

Finansal tutum, bireylerin gelecekte planladığı yatırımların ve tüketim harcamalarının gerçekleşmesinde önemli bir paya sahiptir (Namlı ve Kaya, 2018, 2). Bireylerin finansal davranışları harcama, biriktirme, kazanma, hediye alma şeklinde ortaya çıkabilmektedir (Jorgensen vd., 2017, 59). Geleceğin belirsiz olması, bireylerin ihtiyatlı davranmasını gerektirmektedir. Tüketmek kazanmaktan daha kolay gerçekleşmektedir. Bireyler sınırlı ve sabit gelirleriyle düzenli tasarruf yaparak, arzu ettikleri şeyleri gerçekleştirmek isterler. Tasarruf, sadece gelecekte tüketim yapmak için gerekli fonu önceden temin etmek değil, aynı 
zamanda mevcut fonların en verimli finansal araçlarda değerlendirilerek ekonominin gelişmesi ve kalkınmasına katkı sağlamak için yapılmaktadır.

Finansal bilginin, bireylerin finansal karar ve planlarında gösterdikleri finansal tutum ve davranışlar üzerinde etkili olduğu ifade edilmektedir (Ibrahim ve Alqaydi, 2013, 127). Gençlerin finansal tutum ve davranışları, biyolojik ve psikolojik gelişimlerini tamamlamadan geliştirilmesi gerekmektedir. Bireylerin küçük yaşlarda finansal tutum ve davranışlarını geliştirmek için ailelerin sorumluluk vermeleri ve finansal kabiliyetlerini değerlendirebilmek için kendi finansal kararları almalarına yardımcı olmaları tavsiye edilmektedir (Jorgensen vd., 2017, 57-58).

Finansal bilgi ve tutum, finansal davranışların ortaya çıkışında etkili olduğu ifade edilmektedir. Eksik veya hatalı bilgilerden kaynaklanan finansal davranışlar kişilerin hayatlarını olumsuz yönde etkileyebilmektedir. Örneğin bireylerin gelir-gider dengesinde yanlış finansal tutum ve davranışlar sergilemesi evliliklerin sona ermesine dahi neden olabilmektedir (Parrotta, 1996, 1). Finansal tutum ve davranışlar, bireylerin riske karşı duyarlılıklarını, tüketim eğilimlerini, zevklerini, psikolojik unsurları gibi çok sayıda faktörden etkilenmektedir. Bireylerin hayatlarında yaşadıkları tecrübeler finansal tutum ve davranışlarını etkileyebilmektedir (Alkaya ve Yağlı, 2015, 588). Ayrıca finansal tutum ve davranışların finansal tatmin üzerinde etkili olduğu da ifade edilmektedir (Falahati vd., 2012, 191). Bireylerin finansal davranışlarıyla ilgili çalışmalar incelendiğinde, finansal davranışı ölçmek için harcama ve tasarruf boyutuyla anket geliştirdikleri görülmektedir (Falahati vd., 2012, 191). Örneğin üniversite öğrencilerinin finansal tutum ve davranışlarının incelendiği bir çalışmada kredi kartı kullanma alışkanlığının ve borçlanma eğiliminin arttığı ifade edilmektedir (Borden vd., 2008, 25-26). Bireylerin tutum ve davranışlarının, refah düzeylerini etkilediği ifade edilmektedir (Kirchmaier vd., 2018, 282-283).

\subsection{Literatür Taraması}

$\mathrm{Bu}$ kısımda akademisyenlerin finansal tutum ve davranışlarını inceleyen çalışmalara yer verilmek istenmiştir. Literatürde finansal okuryazarlık başlı̆̆ 1 altında çok sayıda çalışma olup akademisyenlerin finansal tutum ve davranışını doğrudan ölçen anket ya da ölçeğe rastlanılmamıştır. Akademisyenlerin finansal tutum ve davranışlarıyla ilgili yapılmış çalışmalara ulaşılamadığından finansal tutum ve davranışı konu olan çalışmalara yer verilmiştir.

Namlı ve Kaya (2018) lisans öğrencilerinin finansal tutum ve davranışlarını ölçmek amacıyla Spor Bilimleri Fakültesinde öğrenim gören 286 öğrenciye anket yapmıştır. Lisans 
öğrencilerinin çevrelerinden öğrendikleri bilgilerle finansal tutum ve davranışları sergiledikleri tespit edilmiştir. Ayrıca cinsiyet, bölüm ve aylık gelir ile finansal tutum arasında anlamlı bir ilişkinin olduğu, gelir harcama, anne eğitimi ve para yönetimi ile finansal tutum ve davranış arasında farklılıklar olduğu ifade edilmiştir.

Denk vd. (2018) kredi kartlarının finansal davranış ve tutum üzerindeki etkisini incelemiştir. Elazı̆̆ ve Malatya'da faaliyet gösteren 2 AVM'de tesadüf seçilen 420 kişiye anket yapılmıştır. Kartlı ödeme sistemiyle finansal tutum ve davranış arasında istatistiksel açıdan anlamlı bir ilişki olduğu ifade edilmiştir. Kredi kartıyla yapılan harcamalar tüketim davranışını hızlandırdığı tespit edilmiştir.

Er ve Çetindaş (2018), işçilerin finansal okuryazarlık, finansal bilgi, tutum ve davranışlarını incelemiştir. Artvin ilinde çalışan 298 işçiye basit tesadüfi yöntem ile anket yapılmıştır. Anket sonuçlarına göre finansal okuryazarlık düzeyleri yüksek olsa da, gelecek yıllara ait planlarda tasarruflarını artıracak yeterli düzeyde bilgi, tutum ve davranış sergilemedikleri tespit edilmiştir.

Ada (2017) kişisel finans ile ilgili tutum ve davranışları tespit etmeye çalışmıştır. Bu kapsamda Kahramanmaraş ilinde faaliyet gösteren üç özel hastane ile bir üniversite hastanesinde toplam 98 hemşire üzerinde anket uygulaması yapılmıştır. Araştırma sonucunda hemşirelerin finansal tutumlarının sadece gelir düzeyine göre ve finansal davranışlarının ise sadece eğitim durumuna göre farklılık gösterdiği tespit edilmiştir.

Alkaya ve Yağlı (2015) Nevşehir Hacıbektaş Veli Üniversitesi İktisadi ve İdari Bilimler Fakültesi İşletme, İktisat ve Turizm İşletmeciliği ve Otelcilik Bölümü öğrencilerinin finansal bilgi, tutum ve davranışlarını incelemiştir. Fakültede öğrenim gören öğrencilerden kota örneklemesi yöntemiyle seçilen 185 öğrenciye anket yapılmıştır. Finansal tutum ve davranışlar arasında anlamlı bir ilişki olduğu tespit edilmiştir. Öğrencilerin finansal bilgi düzeylerinin yeterli olmadığı ancak olumlu finansal tutum ve davranış sergiledikleri belirtilmiştir.

Ünal ve Düger (2015) akademisyenlerin finansal davranış eğilimlerinin finansal gönenç haline etkilerini incelemişlerdir. Dumlupınar Üniversitesi’nde 246 akademisyenden anket tekniği kullanılarak veri toplanmıştır. Araştırma sonucunda akademisyenlerin finansal davranış eğilimlerinin finansal gönenç hali üzerinde olumlu bir etkisinin olduğu tespit edilmiştir.

Borden vd. (2008) üniversite öğrencilerine finansal bilgi, tutum ve davranışlarını değiştirmek amacıyla seminer yöntemiyle eğitim vermişlerdir. Uygulamada 93 öğrenciye seminer verilmiştir. Eğitim ile öğrencilerin finansal bilgilerinin arttığı, kredi kartına karşı daha 
az risk aldıkları, dolayısıyla eğitimin sonucunda daha etkili finansal davranış sergiledikleri tespit edilmiştir. Eğitim öncesi ve sonrası yapılan testler sonucunda eğitim formatının geniş bir öğrenci kitlesine ulaştığında yararlı olabileceği ifade edilmiştir.

\section{Metodoloji}

$\mathrm{Bu}$ bölümde çalışmanın amacı, soruları, yöntemi ve araştırmada kullanılan ölçekler açıklanmaktadır.

\subsection{Amaç}

$\mathrm{Bu}$ çalışmada akademisyenlerin finansal tutum ve davranışları incelenerek davranışsal finans literatürüne katkı sağlanması amaçlanmaktadır. Bu bağlamda akademisyenlerin finansal tutum ve davranışları cinsiyet, yaş, unvan, medeni durumu, ortalama aylık gelir olmak üzere 5 demografik değişken açısından incelenmektedir.

Araştırmanın amacı doğrultusunda 5 araştırma sorusu geliştirilmiştir:

$\mathbf{S}_{1}$ : Akademisyenlerin finansal tutum ve davranışları cinsiyet değişkeni bakımından farklılık gösterir mi?

S2: Akademisyenlerin finansal tutum ve davranışları yaş değişkeni bakımından farklılık gösterir mi?

S3: Akademisyenlerin finansal tutum ve davranışları unvan değişkeni bakımından farklılık gösterir mi?

S4: Akademisyenlerin finansal tutum ve davranışları medeni durum değişkeni bakımından farkl1lık gösterir mi?

S5: Akademisyenlerin finansal tutum ve davranışları ortalama aylık gelir değişkeni bakımından farklılık gösterir mi?

\subsection{Yöntem}

Bu çalışmada nicel araştırma yöntemi kullanılmıştır. Bu kapsamda araştırmanın veri toplama aşamasında sosyal bilimlerde sıklıkla kullanılan anket tekniği tercih edilmiştir. Türkiye`de Karadeniz Bölgesi’ndeki tüm üniversitelerde görev yapan tüm akademisyenler (Prof. Dr., Doç. Dr, Dr. Öğr. Üyesi, Öğr. Gör. ve Arş. Gör.) araştırmanın evrenini oluşturmaktadır. Karadeniz Bölgesi’nde 1 vakıf statüsünde, 20 devlet statüsünde olmak üzere 21 üniversite bulunmaktadır. Bu üniversitelerde görev yapan toplam akademisyen sayısı Yükseköğretim Kurulu nun Yükseköğretim Bilgi Sistemi veri tabanından alınan güncel verilere göre 18.848 olarak belirlenmiştir (YÖK, 2018). Ancak araştırmada sadece İktisadi ve İdari Bilimler alanında görev yapan "Prof. Dr., Doç. Dr., Dr. Öğr. Üyesi, Öğr. Gör. ve Arş. Gör." 
unvanlarına sahip tüm akademisyenler seçilmiş ve tüm üniversitelerin web sayfalarında yer alan mail adreslerinden oluşan yaklaşık 1.300 akademisyene 2018-2019 eğitim-öğretim güz yarıyılında mail gönderilmiştir. Araştırma evreninden $\% 95$ güven düzeyinde ve $\% 5$ güven aralığı dikkate alınarak Sample Size Calculator programında yapılan hesaplama sonucunda örneklem büyüklüğü minimum 377 kişi olarak hesaplanmıştır. Elektronik ortamda oluşturulan anket formu kolayda örnekleme yöntemi kullanılarak akademisyenlere dağıtılmış ve 405 akademisyenden geri dönüş sağlanmıştır. Anket dağıtım sürecinin eğitim-öğretim döneminin başlarına rastlaması, bu dönemde akademisyenlerin yoğunluğu düşünüldüğünde araştırmanın önemli bir kısıtı olarak kabul edilmektedir. Araştırmada elde edilen veriler SPSS 22,0 programında frekans, yüzde, ortalama, standart sapma, güvenilirlik, faktör analizi ve tek yönlü varyans (ANOVA) analizlerine tabi tutularak yorumlanmıştır.

\section{3. Ölçekler}

Araştırmada kullanılan anket formu iki bölümden oluşmaktadır. Birinci bölümde akademisyenlerin cinsiyet, yaş, unvan, medeni durum, ortalama aylık gelir ile ilgili demografik bilgilerini tespit etmek amacıyla 5 sorudan oluşan bir soru formu kullanılmıştır. İkinci bölümde ise akademisyenlerin finansal tutum ve davranışlarını tespit etmek amacıyla Sarı̈ül (2015) tarafından geliştirilen "Finansal Tutum ve Davranış Ölçeği (FTDÖ)" kullanılmıştır. Bu ölçek yazarlar tarafından aslına uygun bir şekilde akademisyenlere uygulanacak şekilde uyarlanmıştır. Harcama, tutum, algı ve ilgi olmak üzere 4 boyuttan oluşan FTDÖ akademisyenlerin finansal tutum ve davranışlarını ölçmeyi amaçlamaktadır. Ölçek maddelerinin derecelendirilmesinde 5 li likert tipi (1: Kesinlikle Katılmıyorum, 2: Katılmıyorum, 3: Kararsızım, 4: Katılıyorum, 5: Kesinlikle Katılıyorum) ölçek kullanılmıştır.

Yapılan analiz sonucunda FTDÖ’nün güvenilirlik değerleri tespit edilerek Tablo 1`de gösterilmektedir.

Tablo 1. FTDÖ Boyutlarının Güvenilirlik Değerleri

\begin{tabular}{|l|l|l|l|l|l|}
\hline \multicolumn{2}{|l|}{ Ölçekler } & \multicolumn{2}{|l|}{ Madde Sayıs } & \multicolumn{2}{|l|}{ Cronbach Alfa $(\alpha)$} \\
\hline \multirow{3}{*}{ FTDÖ } & Harcama & 3 & \multirow{3}{*}{10} & 0,639 & \multirow{2}{*}{0,714} \\
\cline { 2 - 3 } & Tutum & 4 & 0,661 & 0,714 \\
\cline { 2 - 3 } & İlgi & 3 & & 0,601 & \\
\hline
\end{tabular}

Tablo 1 incelendiğinde FTDÖ`nün Cronbach Alfa $(\alpha)$ değeri 0,60-0,80 $(0,714)$ arasında olduğundan ölçeğin oldukça güvenilir olduğu söylenebilir. FTDÖ ayrıntılı incelendiğinde "harcama", "tutum" ve "ilgi” alt boyutlarının Cronbach Alfa $(\alpha)$ değerlerinin sirasıyla 0, 639, 
0,661, 0,601 olduğu ve bu boyutların güvenilir düzeyde oldukları görülmektedir. Ancak "algı" boyutunun Cronbach Alfa $(\alpha)$ değerinin 0,00-0,40 $(0,346)$ arasında olduğundan bu boyutun güvenilir olmadığı sonucuna ulaşılmış ve bu boyut analiz dişı bırakılmıştır. "Algı" boyutunda yer alan ifadelerin finansal algıyı ölçmediği düşünülmektedir. Ayrıca ölçeğin "harcama" boyutunda yer alan "Alışveriş yapmak mutluluğum için çok önemlidir" maddesi "harcama" boyutunun güvenilirliğini 0,60 seviyesinin altına düşürdüğünden dolayı bu madde de analiz dişı bırakılmıştır (Kayış, 2009, 403-405).

\section{Bulgular}

Bu bölümde faktör analizi bulguları, demografik bulgular, tanımlayıcı istatistiki bulgular ve araştırma sorularına ilişkin bulgular yer almaktadır.

\subsection{Faktör Analizi Bulguları}

Sosyal araştırmalarında sıklıkla kullanılan faktör analizi, birbirleriyle ilişkili çok sayıda değişkeni bir araya toplayarak daha az sayıda anlamlı yeni değişkenler (faktörler, boyutlar) keşfetmeyi ya da doğrulamayı amaçlayan ve ölçeklerin geçerliliğinin test edilmesinde kullanılan çok değişkenli istatistiksel bir analiz tekniğidir (Yaşlıoğlu, 2017: 75). Bu bağlamda faktör analizinin açıklayıcı (keşfedici) ve doğrulayıcı olmak üzere iki türü bulunmaktadır. Açıklayıcı faktör analizi, değişkenler arası ilişkilerden hareketle faktör bulmaya ve teori geliştirmeye yönelik bir işlem iken, doğrulayıcı faktör analizi ise değişkenler arası ilişkilere dair önceden belirlenen bir modelin ya da hipotezin test edilmesine ya da doğrulanmasına yönelik bir işlemdir (Büyüköztürk, 2002, 472). Böylece faktör analizi ile birden fazla değişken birkaç başlık altında toplanarak bir "faktör yükü” elde edilebilmektedir (Çetin, 2007, 59). Faktör yükü aynı zamanda "açıklama katsayısı" olarak ifade edilebilir. Çalışmada akademisyenlerin finansal tutum ve davranışlarını belirleyen ifadeler faktörlere bölünmesi düşünüldüğünden Açıklayıcı Faktör Analizi uygulanması uygun görülmüş ve araştırmadan elde edilen veriler Açıklayıcı Faktör Analizine (AFA) tabi tutulmuştur. AFA ile ilgili bulgular Tablo 2 ve Tablo $3 `$ de verilmektedir.

Tablo 2. FTDÖ Alt Boyutlarının Varyans Açıklama Yüzdeleri

\begin{tabular}{|l|l|l|l|l|}
\hline Boyutlar & $\begin{array}{l}\text { Madde } \\
\text { Sayısı }\end{array}$ & $\begin{array}{l}\text { Varyanslı Birikimli } \\
\text { Açlama Yüzdesi } \\
(\%)\end{array}$ & KMO & Sig. \\
\hline Harcama & 3 & 59,390 & 0,542 & 0,000 \\
\hline Tutum & 4 & 50,868 & 0,719 & 0,000 \\
\hline
\end{tabular}




\begin{tabular}{|l|l|l|l|l|}
\hline İlgi & 3 & 55,757 & 0,633 & 0,000 \\
\hline
\end{tabular}

FTDÖ alt boyutlarının açıklama yüzdeleri incelendiğinde "harcama" boyutunun en yüksek $(59,390)$ açıklama yüzdesine sahip olduğu görülmektedir. Bu durum finansal tutum ve davranış eğilimlerinin en çok "harcama" davranışları ile açıklanabileceğini göstermektedir. Dolayısıyla finansal tutum ve davranış eğilimlerinin en çok harcama davranışında görülebileceği söylenebilir. Ayrıca KMO değerlerinin 0,5 in üzerinde olması, bu ölçeğin örneklem yeterliliği açısından yeterli düzeyde olduğunu göstermektedir (Field, 2009, 647). KMO değerleri incelendiğinde "tutum” boyutunun örneklem yeterliliği açısından oldukça iyi olduğu görülmektedir. Tablo 3 `de FTDÖ yü oluşturan boyutlara ait faktör yükleri verilmiştir.

Tablo 3. FTDÖ `nin Faktör Yükü Matrisi

\begin{tabular}{|c|c|c|c|}
\hline \multirow[b]{2}{*}{ Ölçek Maddeleri } & \multicolumn{3}{|c|}{$\begin{array}{l}\text { Faktörler-Açılama } \\
\text { Katsayıları }\end{array}$} \\
\hline & Harcama & $\begin{array}{l}\text { Tutu } \\
m\end{array}$ & $\dot{I l g i}$ \\
\hline $\begin{array}{l}\text { Para, harcanmak içindir, biriktirmek için } \\
\text { değildir. }\end{array}$ & 0,459 & & \\
\hline Harcamalarımı kontrol etmekte zorlanırım. & 0,883 & & \\
\hline Paramın nasıl bittiğini anlamam. & 0,889 & & \\
\hline $\begin{array}{l}\text { Planlanmamış harcamalar için kenarda para } \\
\text { bulundurulmalıdır. }\end{array}$ & & 0,628 & \\
\hline Haftalık ve aylık harcama planlarl yaparım. & & 0,714 & \\
\hline Alışveriş yaparken fiyatları kıyaslarım. & & 0,729 & \\
\hline $\begin{array}{l}\text { Bir şey satın alırken finansal durumumu dikkate } \\
\text { alırım. }\end{array}$ & & 0,774 & \\
\hline Parasal konular ilgimi çekmez. & & & 0,744 \\
\hline Finans konularında eğitim almak isterim. & & & 0,716 \\
\hline $\begin{array}{l}\text { Gazetelerin ve televizyonları ekonomi ve finans } \\
\text { haberlerini takip ederim. }\end{array}$ & & & 0,779 \\
\hline
\end{tabular}

AFA sonucunda FTDÖ maddelerinin 3 faktör (harcama, tutum, ilgi) altında toplandığ1 görülmektedir. Bu bulgu ölçeğin yapı geçerliliği olduğunu göstermektedir. Tablo $3 `$ de verilen faktör yükleri incelendiğinde "harcama" boyutunu en çok "Paramın nasıl bittiğini anlamam $(0,889)$ " ifadesinin açıkladığı, "tutum” boyutunu en çok "Bir şey satın alırken finansal durumumu dikkate alırım $(0,774)$ " ifadesinin açıkladığı, "ilgi" boyutunu ise "Gazetelerin ve televizyonların ekonomi ve finans haberlerini takip ederim $(0,779)$ ” ifadesinin açıkladığı anlaşılmaktadır. 


\subsection{Demografik Bulgular}

Araştırma kapsamında anket tekniği ile veri toplanan 405 akademisyenin cinsiyet, yaş, unvan, medeni durum ve ortalama aylık gelir ile ilgili demografik bilgileri Tablo 4 `de verilmiştir.

Tablo 4. Katılımcılarla İlgili Demografik Bulgular

\begin{tabular}{|c|c|c|c|}
\hline & & $N$ & $\mid \begin{array}{l}\text { Yüzde } \\
(\%)\end{array}$ \\
\hline \multirow[t]{3}{*}{ Cinsiyet } & Erkek & 250 & 61,7 \\
\hline & Kadın & 155 & 38,3 \\
\hline & Toplam & 405 & 100 \\
\hline \multirow[t]{6}{*}{ Yaş } & $20-29$ & 86 & 21,2 \\
\hline & $30-39$ & 217 & 53,6 \\
\hline & $40-49$ & 68 & 16,8 \\
\hline & $50-59$ & 31 & 7,7 \\
\hline & 60 ve üzeri & 3 & 0,7 \\
\hline & Toplam & 405 & 100 \\
\hline \multirow[t]{3}{*}{ Medeni Durum } & Bekâr & 134 & 33,1 \\
\hline & Evli & 271 & 66,9 \\
\hline & Toplam & 405 & 100 \\
\hline \multirow[t]{6}{*}{ Unvan } & Prof. Dr. & 23 & 5,7 \\
\hline & Doç. Dr. & 34 & 8,4 \\
\hline & Dr. Öğr. Üyesi & 135 & 33,3 \\
\hline & Öğr. Gör. & 84 & 20,7 \\
\hline & Arş. Gör. & 129 & 31,9 \\
\hline & Toplam & 405 & 100 \\
\hline \multirow{6}{*}{$\begin{array}{l}\text { Ortalama Aylık Gelir } \\
\text { (maaş ve diğer } \\
\text { gelirler) }\end{array}$} & $4.000-6.000 \mathrm{TL}$ & 212 & 52,3 \\
\hline & $6.001-8.000 \mathrm{TL}$ & 131 & 32,3 \\
\hline & $8.001-10.000 \mathrm{TL}$ & 40 & 9,9 \\
\hline & $10.001-12.000 \mathrm{TL}$ & 11 & 2,7 \\
\hline & 12.001 TL ve üzeri & 11 & 2,7 \\
\hline & Toplam & 405 & 100 \\
\hline
\end{tabular}

Tablo 4 incelendiğinde katılımcıların yarıdan fazlasının $(250$ kişi=\%61,7) erkek olduğu görülmektedir. Bu sonuç üniversitelerde erkek akademisyenlerin kadın akademisyenlerden fazla olmasından kaynaklandığını göstermektedir. Yine katılımcıların yarıdan fazlasının 30-39 yaş aralığında $(217$ kişi=\%53,6) olduğu görülmektedir. Medeni durum açısından bakıldığında katılımcıların aynı şekilde yarıdan fazlasının evli $(271=\% 66,9)$ olduğu sonucuna ulaşılmaktadır. $\mathrm{Bu}$ durum akademisyenlerin büyük oranda evli olduğunu göstermektedir. Unvan açısından bakıldığında ise Dr. Öğr. Üyesi (135 kişi=\%33,3) ve Arş. Gör. (129 kişi= 
\%31,9) unvanlı akademisyenlerin araştırmaya daha çok katıldığı görülmektedir. Yaş değişkeni ve unvan değişkenine ilişkin sonuçlar birlikte değerlendirildiğinde 30-39 yaş aralığındaki ve Dr. Öğr. Üyesi ile Arş. Gör. unvanlı akademisyenlerin araştırmaya daha fazla katkı sağladı1kları görülmektedir. Son olarak ortalama aylık gelir değişkeni ile ilgili verilere bakıldığında katılımcıların yarıdan fazlasının 4.000-6.000 TL dolayında gelire sahip olduğu görülmektedir. Bu durum yaş ve unvan değişkenine ilişkin sonuçları doğrular niteliktedir.

\subsection{Tanımlayıcı İstatistiki Bulgular}

$\mathrm{Bu}$ bölümde araştırmaya katılan akademisyenlerin finansal tutum ve davranışlarına ilişkin tanımlayıcı istatistiki bulgular yer almaktadır. Bu kapsamda anket formunda yer alan ifadelere verilen cevaplara yönelik frekans, ortalama, standart sapma, çarpıklık ve basıklık değerleri Tablo 5 `de verilmektedir.

Tablo 5. Tanımlayıcı İstatistiki Bulgular

\begin{tabular}{|c|c|c|c|c|c|}
\hline İfadeler & $N$ & $\begin{array}{l}\text { Ortalam } \\
a(X)\end{array}$ & $\begin{array}{l}\text { Standart } \\
\text { Sapma }\end{array}$ & $\begin{array}{l}\text { Çarpiklık } \\
\text { (Skewness } \\
\text { ) }\end{array}$ & $\begin{array}{l}\text { Basiklık } \\
\text { (Kurtosis } \\
\text { ) }\end{array}$ \\
\hline Harcama & 405 & 2,5160 & 0,87671 & 0,462 & $-0,359$ \\
\hline $\begin{array}{l}\text { Para, harcanmak } \\
\text { içindir, biriktirmek } \\
\text { için değildir. }\end{array}$ & 405 & 2,793 & 1,0561 & 0,182 & $-0,497$ \\
\hline $\begin{array}{l}\text { Harcamalarımı } \\
\text { kontrol etmekte } \\
\text { zorlanırım. }\end{array}$ & 405 & 2,360 & 1,1338 & 0,600 & $-0,503$ \\
\hline $\begin{array}{l}\text { Paramin nasıl } \\
\text { bittiğini anlamam. }\end{array}$ & 405 & 2,395 & 1,2495 & 0,634 & $-0,657$ \\
\hline Tutum & 405 & 4,0605 & 0,6786 & $-0,580$ & 0,124 \\
\hline $\begin{array}{l}\text { Planlanmamış } \\
\text { harcamalar için } \\
\text { kenarda para } \\
\text { bulundurulmalıdır. }\end{array}$ & 405 & 4,516 & 0,6950 & $-1,680$ & 3,810 \\
\hline $\begin{array}{l}\text { Haftalık ve ayllk } \\
\text { harcama planları } \\
\text { yaparım. }\end{array}$ & 405 & 3,319 & 1,2427 & $-0,288$ & $-1,000$ \\
\hline $\begin{array}{l}\text { Alışveriş yaparken } \\
\text { fiyatları klyaslarım. }\end{array}$ & 405 & 4,052 & 0,9849 & $-1,010$ & 0,595 \\
\hline $\begin{array}{l}\text { Bir şey satın alırken } \\
\text { finansal durumumu } \\
\text { dikkate alırım. }\end{array}$ & 405 & 4,356 & 0,8455 & $-1,614$ & 2,938 \\
\hline Illgi & 405 & 2,9440 & 0,6589 & $-0,293$ & 0,323 \\
\hline $\begin{array}{l}\text { Parasal konular } \\
\text { ilgimi çekmez. }\end{array}$ & 405 & 2,175 & 1,1652 & 0,843 & $-0,194$ \\
\hline $\begin{array}{l}\text { Finans konularında } \\
\text { eğitim almak isterim. }\end{array}$ & 405 & 3,262 & 1,3166 & $-0,309$ & $-1,043$ \\
\hline
\end{tabular}




\begin{tabular}{|l|l|l|l|l|l|}
\hline $\begin{array}{l}\text { Gazetelerin ve } \\
\text { televizyonlartn } \\
\text { ekonomi ve finans } \\
\text { haberlerini takip } \\
\text { ederim. }\end{array}$ & 405 & 3,395 & 1,2943 & $-0,442$ & $-0,898$ \\
\hline
\end{tabular}

Tablo 5 'de verilen ortalamalar incelendiğinde "harcama" boyutunun $(\mathrm{X}=2,5)$ "Kararsızım (3)" düzeyine yakın, "tutum" boyutunun ( $X=4,1$ ) "Katılıyorum (4)" düzeyinde ve "ilgi" boyutunun ise $(X=2,9)$ "Kararsızım (3)" düzeyinde olduğu görülmektedir. Bu durum akademisyenlerin finansal harcama eğilimlerinin ve finansal ilgilerinin orta düzeyde, finansal tutumlarının ise orta düzeyin üzerinde olduğunu göstermektedir. $\mathrm{Bu}$ sonuçlara göre akademisyenlerin finansal konularda bilgi sahibi oldukları düşünüldügüñnde bu bilginin finansal tutum ve davranışlarına yansıdığı söylenebilir. Tablo 5`e göre en yüksek ortalamaya sahip ifadeler "harcama" boyutunda "Para, harcanmak içindir, biriktirmek için değildir" $(\mathrm{X}=2,8)$, "tutum" boyutunda "Planlanmamış harcamalar için kenarda para bulundurulmalıdır" $(X=4,5)$ ve "ilgi" boyutunda ise "Gazetelerin ve televizyonların ekonomi ve finans haberlerini takip ederim" $(X=3,4)$ ifadeleri olduğu görülmektedir. Buna göre akademisyenler paranın hem harcama hem de bir birikim aracı olduğunu, olağanüstü durumlar için para biriktirilmesi gerektiğini ve ekonomi-finans ile ilgili gelişmelerin takip edilmesi gerektiğini düşünmektedirler. Bu sonuç akademisyenlerin finansal tutum ve davranışlarında bilinçli ve dengeli olduklarını göstermektedir.

Tablo 5`de bulunan çarpıklık (skewness) ve basıklık (kurtosis) değerleri anket verilerinin normal dağılıp dağılmadığını göstermektedir. Çarpıklık ve basıklık katsayıları - $\infty$ ile $+\infty$ arasında değerler almaktadır. Çarpıklık ve basıklık katsayılarının -3 ve +3 arasında değerler alması durumunda verilerin normal dağıldığı kabul edilmektedir (Ak, 2009, s. 6-7). Normal dağılım, verilerin simetrik dağılımını ifade etmekte ve "çan” şeklindeki eğri ile gösterilmektedir. Bu şekilde değerlerin büyük çoğunluğu merkezin etrafında toplanmaktadır (Field, 2009, s. 18). İstatistiksel analizlerde sağlıklı sonuçların elde edilebilmesi için verilerin normal dağılım ya da normale yakın dağılım göstermesi gerekmektedir. Bu nedenle, verilerin normal dağılım gösterip göstermediğini tespit etmek için çarpıklık ve basıklık değerlerine bakılmıştır. Tablo 5'de çarpıklık ve basıklık değerlerinin -3 ve +3 arasında olduğu görülmektedir. Buna göre verilerin normal dağılım gösterdiği kabul edilmiş ve araştırma sorularının test edilmesinde parametrik testlerin (t-testi ve ANOVA) yapılması uygun görülmüştür. 


\subsection{Araşırma Sorularına Yönelik Bulgular}

Araştırma kapsamında geliştirilen sorular t-testi ve tek yönlü varyans (ANOVA) analizi ile test edilmiştir. Cinsiyet ve medeni durum değişkenleri için 1 ve 4 . soruların test edilmesinde t-testi, diğer soruların test edilmesinde ise ANOVA analizi kullanılmıştır.

Akademisyenlerin finansal tutum ve davranışlarının (harcama, tutum, ilgi) cinsiyet değişkeni açısından anlamlı bir farklılık gösterip göstermediği t-testi ile test edilmiş olup analiz sonuçları Tablo 6 'da verilmektedir $\left(S_{1}\right)$.

Tablo 6. Cinsiyet Değişkenine Göre T-Testi Sonuçları

\begin{tabular}{|c|c|c|c|c|c|c|c|c|}
\hline Boyutlar & Cinsiyet & $N$ & Ort. (X) & $\begin{array}{l}\text { Homojenlik } \\
\text { Durumu }\end{array}$ & $F$ & Sig. & $t$ & $\begin{array}{l}\text { Sig. } \\
(2- \\
\text { tailed })\end{array}$ \\
\hline \multirow[t]{2}{*}{ Harcama } & Erkek & 250 & 2,5680 & $\begin{array}{l}\text { Varyanslar } \\
\text { homojen. }\end{array}$ & \multirow{2}{*}{0,000} & \multirow{2}{*}{0,988} & 1,519 & 0,130 \\
\hline & Kadın & 155 & 2,4323 & $\begin{array}{l}\text { Varyanslar } \\
\text { homojen değil. }\end{array}$ & & & 1,529 & 0,127 \\
\hline \multirow[t]{2}{*}{ Tutum } & Erkek & 250 & 4,0720 & $\begin{array}{l}\text { Varyanslar } \\
\text { homojen. }\end{array}$ & \multirow{2}{*}{0,080} & \multirow{2}{*}{0,778} & 0,433 & 0,665 \\
\hline & Kadın & 155 & 4,0419 & \begin{tabular}{|l|} 
Varyanslar \\
homojen değil.
\end{tabular} & & & 0,435 & 0,664 \\
\hline \multirow[t]{2}{*}{ İlgi } & Erkek & 250 & 3,0107 & $\begin{array}{l}\text { Varyanslar } \\
\text { homojen. }\end{array}$ & \multirow{2}{*}{0,003} & \multirow{2}{*}{0,953} & 2,603 & $\mathbf{0 , 0 1 0}$ \\
\hline & Kadın & 155 & 2,8366 & $\begin{array}{l}\text { Varyanslar } \\
\text { homojen değil. }\end{array}$ & & & 2,626 & 0,009 \\
\hline
\end{tabular}

Sig. değerinin 0,05 ten büyük olması varyansların homojen olduğunu göstermektedir. Bu durumda Sig. (2-tailed) değerleri incelendiğinde kadın ve erkek arasında sadece "ilgi" boyutunda anlamlı bir fark olduğu (Sig. <0,05), "harcama" ve "tutum" boyutunda anlamlı bir fark olmadığı tespit edilmiştir. "İlgi” boyutunda ortalamalar incelendiğinde erkeklerin $\mathrm{X}=3,01$, kadınların ise $\mathrm{X}=2,84$ olduğu, erkeklerin finansal konulara kadınlardan daha çok ilgili olduğu görülmektedir.

Akademisyenlerin finansal tutum ve davranışlarının (harcama, tutum, ilgi) yaş değişkeni açısından anlamlı bir farklılık gösterip göstermediği ANOVA ile test edilmiş olup analiz sonuçları Tablo 7`de verilmektedir $\left(S_{2}\right)$.

Tablo 7. Yaş Değişkenine Göre ANOVA Sonuçları

\begin{tabular}{|c|c|c|c|c|c|}
\hline Boyutlar & 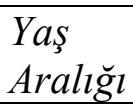 & $N$ & $\begin{array}{l}\text { Ort. } \\
(X)\end{array}$ & $F$ & \begin{tabular}{|l} 
Sig. \\
$(0,05)$
\end{tabular} \\
\hline \multirow{3}{*}{ Harcama } & $20-29$ & 86 & 2,6589 & \multirow{3}{*}{1,732} & \multirow{3}{*}{0,142} \\
\hline & $30-39$ & 217 & 2,5253 & & \\
\hline & $40-49$ & 68 & 2,4314 & & \\
\hline
\end{tabular}




\begin{tabular}{|c|c|c|c|c|c|}
\hline & $50-59$ & 31 & 2,2151 & & \\
\hline & $\begin{array}{l}60 \text { ve } \\
\text { üzeri }\end{array}$ & 3 & 2,7778 & & \\
\hline & Toplam & 405 & 2,5160 & & \\
\hline & $20-29$ & 86 & 4,0029 & & \\
\hline & $30-39$ & 217 & 4,1071 & & \\
\hline & $40-49$ & 68 & 3,9596 & & \\
\hline Tutum & $50-59$ & 31 & 4,0806 & 1001 & \\
\hline & $\begin{array}{l}60 \text { ve } \\
\text { üzeri }\end{array}$ & 3 & 4,4167 & 1,001 & 0,407 \\
\hline & Toplam & 405 & 4,0605 & & \\
\hline & $20-29$ & 86 & 2,9690 & & \\
\hline & $30-39$ & 217 & 2,9954 & & \\
\hline & $40-49$ & 68 & 2,7108 & & \\
\hline Ilgi & $50-59$ & 31 & 3,0215 & 2646 & 0033 \\
\hline & $\begin{array}{l}60 \text { ve } \\
\text { üzeri }\end{array}$ & 3 & 3,0000 & 2,040 & 0,053 \\
\hline & Toplam & 405 & 2,9440 & & \\
\hline
\end{tabular}

Tablo 7 incelendiğinde yaş değişkeni açısından sadece "ilgi" boyutunda anlamlı bir farklılık olduğu (Sig. $<0,05)$, diğer boyutlarda (harcama, tutum) anlamlı bir farklılık olmadığı tespit edilmiştir. "İlgi”" boyutuna ilişkin ortalamalar incelendiğinde finansal konulara ilginin yaş arttıkça arttığı görülmektedir. Bu durumun yaşın artmasıyla birlikte bilgi ve deneyimin artmasından kaynaklandığı söylenebilir.

Akademisyenlerin finansal tutum ve davranışlarının (harcama, tutum, ilgi) medeni durum değişkeni açısından anlamlı bir farklılık gösterip göstermediği t-testi ile test edilmiş olup analiz sonuçları Tablo $8^{`}$ de verilmektedir $\left(S_{3}\right)$.

Tablo 8. Medeni Durum Değişkenine Göre T-Testi Sonuçları

\begin{tabular}{|c|c|c|c|c|c|c|c|c|}
\hline Boyutlar & Cinsiyet & $N$ & Ort. $(X)$ & $\begin{array}{l}\text { Homojenlik } \\
\text { Durumu }\end{array}$ & $F$ & Sig. & $t$ & $\begin{array}{l}\text { Sig. } \\
(2- \\
\text { tailed) }\end{array}$ \\
\hline \multirow[t]{2}{*}{ Harcama } & Evli & 271 & 2,4244 & Homojen. & \multirow{2}{*}{5,633} & \multirow{2}{*}{0,018} & $-3,027$ & 0,003 \\
\hline & Bekâr & 134 & 2,7015 & Homojen değil. & & & $-2,908$ & 0,004 \\
\hline \multirow[t]{2}{*}{ Tutum } & Evli & 271 & 4,1522 & Homojen. & \multirow{2}{*}{0,307} & \multirow{2}{*}{0,580} & 3,937 & 0,000 \\
\hline & Bekâr & 134 & 3,8750 & Homojen değil. & & & 3,813 & 0,000 \\
\hline \multirow[t]{2}{*}{ İlgi } & Evli & 271 & 2,9164 & Homojen. & \multirow[b]{2}{*}{0,079} & \multirow[b]{2}{*}{0,779} & $-1,203$ & 0,230 \\
\hline & Bekâr & 134 & 3,0000 & $\begin{array}{l}\text { Hhomojen } \\
\text { değil. }\end{array}$ & & & $-1,210$ & 0,227 \\
\hline
\end{tabular}

Sig. değeri incelendiğinde "tutum" ve "ilgi” boyutunda değerlerin 0,05 ten büyük olmas nedeniyle varyansların homojen olduğu, "harcama” boyutunda ise Sig. değeri 0,05 ten küçük olduğundan varyansların homojen olmadığı görülmektedir. Sig. (2-tailed) değerleri 
incelendiğinde evli ve bekâr arasında "harcama" ve "tutum" boyutunda anlamlı bir farkın olduğu (Sig. <0,05), “ilgi”" boyutunda ise olmadığı görülmektedir. Ortalamalar incelendiğinde bekâr akademisyenlerin harcama eğilimlerinin daha yüksek $(X=2,70)$, evli akademisyenlerin ise tutum eğilimlerinin daha yüksek $(\mathrm{X}=4,15)$ olduğu anlaşılmaktadır. $\mathrm{Bu}$ sonuç evli akademisyenlerin finansal tutum ve davranışlarında daha ihtiyatlı oldukları ve finansal planlamaya dikkat ettiklerini göstermektedir.

Akademisyenlerin finansal tutum ve davranışlarının (harcama, tutum, ilgi) unvan değişkeni açısından anlamlı bir farklılık gösterip göstermediği ANOVA ile test edilmiş olup analiz sonuçları Tablo 9` da verilmektedir $\left(S_{4}\right)$.

Tablo 9. Unvan Değişkenine Göre ANOVA Sonuçları

\begin{tabular}{|c|c|c|c|c|c|}
\hline Boyutlar & Unvan & $N$ & Ort. $(X)$ & $F$ & $\begin{array}{l}\text { Sig. } \\
(0,05)\end{array}$ \\
\hline \multirow{6}{*}{ Harcama } & Prof. Dr. & 23 & 2,2609 & \multirow{6}{*}{1,929} & \multirow{6}{*}{0,105} \\
\hline & Doç. Dr. & 34 & 2,4118 & & \\
\hline & Dr. Öğr. Üyesi & 135 & 2,4247 & & \\
\hline & Öğr. Gör. & 84 & 2,6865 & & \\
\hline & Arş. Gör. & 129 & 2,5736 & & \\
\hline & Toplam & 405 & 2,5160 & & \\
\hline \multirow{6}{*}{ Tutum } & Prof. Dr. & 23 & 4,1522 & \multirow{6}{*}{0,548} & \multirow{6}{*}{0,700} \\
\hline & Doç. Dr. & 34 & 4,1838 & & \\
\hline & Dr. Öğr. Üyesi & 135 & 4,0333 & & \\
\hline & Öğr. Gör. & 84 & 4,0833 & & \\
\hline & Arş. Gör. & 129 & 4,0252 & & \\
\hline & Toplam & 405 & 4,0605 & & \\
\hline \multirow{6}{*}{$\dot{I} \lg i$} & Prof. Dr. & 23 & 3,0725 & \multirow{6}{*}{0,652} & \multirow{6}{*}{0,625} \\
\hline & Doç. Dr. & 34 & 2,8431 & & \\
\hline & Dr. Öğr. Üyesi & 135 & 2,9333 & & \\
\hline & Öğr. Gör. & 84 & 2,9008 & & \\
\hline & Arş. Gör. & 129 & 2,9871 & & \\
\hline & Toplam & 405 & 2,9440 & & \\
\hline
\end{tabular}

Tablo 9 incelendiğinde unvan değişkeni bakımından akademisyenlerin finansal tutum ve davranışlarında anlamlı bir farklılık olmadığı (Sig.>0,05) tespit edilmiştir. Bu sonuç tüm akademisyenlerin unvan bakımından benzer harcama, tutum ve ilgi eğilimlerine sahip olduğunu göstermektedir.

Akademisyenlerin finansal tutum ve davranışlarının (harcama, tutum, ilgi) ortalama aylık gelir değişkeni açısından anlamlı bir farklılık gösterip göstermediği ANOVA ile test edilmiş olup analiz sonuçları Tablo $10{ }^{`}$ da verilmektedir $\left(S_{5}\right)$. 
Tablo 10. Ortalama Aylık Gelir Değişkenine Göre ANOVA Sonuçları

\begin{tabular}{|c|c|c|c|c|c|}
\hline Boyutlar & $\begin{array}{l}\text { Ortalama Aylık } \\
\text { Gelir }\end{array}$ & $N$ & Ort. $(X)$ & $F$ & $\begin{array}{l}\text { Sig. } \\
(0,05)\end{array}$ \\
\hline \multirow{6}{*}{ Harcama } & $4.000-6.000 \mathrm{TL}$ & 212 & 2,5283 & \multirow{6}{*}{2,099} & \multirow{6}{*}{0,080} \\
\hline & $6.001-8.000 \mathrm{TL}$ & 131 & 2,5852 & & \\
\hline & $8.001-10.000 \mathrm{TL}$ & 40 & 2,3583 & & \\
\hline & $10.001-12.000 \mathrm{TL}$ & 11 & 2,6667 & & \\
\hline & 12.001 TL ve üzeri & 11 & 1,8788 & & \\
\hline & Toplam & 405 & 2,5160 & & \\
\hline \multirow{6}{*}{ Tutum } & $4.000-6.000 \mathrm{TL}$ & 212 & 4,0601 & \multirow{6}{*}{2,015} & \multirow{6}{*}{0,092} \\
\hline & $6.001-8.000 \mathrm{TL}$ & 131 & 3,9809 & & \\
\hline & $8.001-10.000 \mathrm{TL}$ & 40 & 4,1938 & & \\
\hline & $10.001-12.000 \mathrm{TL}$ & 11 & 4,5000 & & \\
\hline & $12.001 \mathrm{TL}$ ve üzeri & 11 & 4,0909 & & \\
\hline & Toplam & 405 & 4,0605 & & \\
\hline \multirow{6}{*}{$\dot{I l g i}$} & $4.000-6.000 \mathrm{TL}$ & 212 & 2,9497 & \multirow{6}{*}{1,090} & \multirow{6}{*}{0,361} \\
\hline & $6.001-8.000 \mathrm{TL}$ & 131 & 2,9415 & & \\
\hline & $8.001-10.000 \mathrm{TL}$ & 40 & 2,8417 & & \\
\hline & $10.001-12.000 \mathrm{TL}$ & 11 & 3,3030 & & \\
\hline & $12.001 \mathrm{TL}$ ve üzeri & 11 & 2,8788 & & \\
\hline & Toplam & 405 & 2,9440 & & \\
\hline
\end{tabular}

Tablo 9 incelendiğinde ortalama aylık gelir değişkeni bakımından akademisyenlerin finansal tutum ve davranışlarında anlamlı bir farklılık olmadığı (Sig. $>0,05)$ tespit edilmiştir.

\section{Sonuç ve Öneriler}

$\mathrm{Bu}$ çalışmada akademisyenlerin finansal tutum ve davranışları incelenmiştir. Çalışmada iktisadi ve idari bilimler alanlarında görev yapan akademisyenlerin finansal konularda bilgi sahibi oldukları düşünüldüğünden, bu bilginin finansal tutum ve davranışlarına harcama, tutum ve ilgi yönünden yansıyıp yansımadığı araştırılmıştır. Genel olarak akademisyenlerin finans bilgilerinin, finansal tutum ve davranışlarına çeşitli şekillerde yansıdığ 1 anlaşılmakla birlikte analizden elde edilen bulgular şunlardır:

Birinci olarak, kadın ve erkek akademisyenlerin finansal ilgilerinde anlamlı bir fark olduğu, finansal harcama ve tutumlarında ise anlamlı bir fark olmadığı tespit edilmiştir. Erkek akademisyenlerin finansal konulara kadın akademisyenlerden daha fazla ilgi gösterdiği sonucuna ulaşılmıştır. Bu durum erkeklerin kazançlarını finansal piyasalarda değerlendirme isteğinde olduklarını göstermektedir.

İkinci olarak, akademisyenlerin yaş değişkeni açısından finansal ilgilerinde anlamlı bir farklılık olduğu, finansal harcama ve tutumlarında anlamlı bir fark olmadığı tespit edilmiştir. Akademisyenlerde finansal konulara ilginin yaş arttıkça arttığı sonucuna ulaşılmıştır. Bu 
durumun yaşın artmasıyla birlikte bilgi, deneyim ve duyarlılığın artmasından kaynaklandığı söylenebilir.

Üçüncü olarak, evli ve bekâr akademisyenler arasında finansal harcama ve finansal tutumlarında anlamlı bir farklılı̆̆ın olduğu, finansal ilgilerinde ise anlamlı bir farklılığın olmadığı görülmektedir. Bekâr akademisyenlerin finansal harcama eğilimlerinin daha yüksek, evli akademisyenlerin ise finansal tutum eğilimlerinin daha yüksek olduğu sonucuna ulaşılmıştır. $\mathrm{Bu}$ durumun evli akademisyenlerin finansal tutum ve davranışlarında daha ihtiyatlı olması ve finansal planlamaya daha fazla dikkat etmelerinden kaynaklandığı düşünülmektedir.

Dördüncü olarak, unvan değişkeni bakımından akademisyenlerin finansal tutum ve davranışlarında anlamlı bir farklılık olmadığı tespit edilmiştir. $\mathrm{Bu}$ sonuç tüm akademisyenlerin unvan bakımından benzer finansal harcama, tutum ve ilgi eğilimlerine sahip olduklarını göstermektedir. Ancak beklenen sonuç akademisyenlerin finansal tutum ve davranışlarının unvanlarına göre farklılık göstermesiydi. Bu bakımdan bu sonucun tartışmalı olduğu düşünülmektedir.

Beşinci (son) olarak, ortalama aylık gelir değişkeni bakımından akademisyenlerin finansal tutum ve davranışlarında anlamlı bir farklılık olmadığı tespit edilmiştir. $\mathrm{Bu}$ sonuç akademisyenlerin ortalama aylık gelir bakımından benzer finansal harcama, tutum ve ilgi eğilimlerine sahip olduklarını göstermektedir. Ancak bu sonuç unvan değişkeninde olduğu gibi beklenen bir durum değildir. Bu açıdan bu sonucun tartışmalı olduğu söylenebilir.

$\mathrm{Bu}$ sonuçların dışında akademisyenler paranın hem harcama hem de bir birikim aracı olduğunu, olağanüstü durumlar için para biriktirilmesi gerektiğini ve ekonomi-finans ile ilgili gelişmelerin takip edilmesi gerektiğini düşünmektedirler. $\mathrm{Bu}$ durum akademisyenlerin finansal tutum ve davranışlarında bilinçli olduklarını ve dengeli davrandıklarını göstermektedir.

Nicel özelliği taşıyan bu araştırmada anket tekniği kullanılmış olup katılımcıların finansal tutum ve davranış ifadelerine ilişkin görüşleri tam olarak araştırmaya yansımadığ düşünülmektedir. Ancak analiz sonucuna göre bulgular akademisyenlerin finansal bilgilerinin finansal tutum ve davranışlarına yansıdığını göstermektedir. Gelecekte yapılacak çalışmalarda nitel araştırma kapsamında görüşme tekniği ile bir araştırmanın yapılması önerilmektedir. 


\section{KAYNAKÇA}

Ada, Ş. 2017. "Sağlık çalışanlarının kişisel finans ile ilgili tutum ve davranışları: Kahramanmaraş ilinde bir araştırma." Selçuk Üniversitesi Sosyal ve Teknik Araştırmalar Dergisi, 14:186-198.

Ak, B. 2009. Verilerin düzenlenmesi ve gösterimi. Ş. Kalaycı içinde, SPSS uygulamalı çok değişkenli istatistik teknikleri (s. 1-47). Ankara: Asil Yayın Dağıtım.

Alkaya, A., \& Yağlı, İ. 2015. "Finansal okuryazarlık, finansal bilgi, davranış ve tutum: Nevşehir Hacıbektaş Veli Üniversitesi İIBF öğrencileri üzerine bir uygulama." Uluslararası Sosyal Araştırmalar Dergisi, 8(40): 585-599.

Allport, G. W. 1935. Attitudes. C. Murchison içinde, Handbook of social psychology (s. 798-844). Worcester: Clark University Press.

Borden, L. M., Lee, S. A., Serido, J., \& Collins, D. 2008. "Changing college students' financial knowledge, attitudes, and behavior through seminar participation." Journal of Family and Economic, 29(1): 23-40.

Büyüköztürk, Ş. 2002. "Faktör analizi: temel kavramlar ve ölçek geliştirmede kullanımı." Kuram ve Uygulamada Eğitim Yönetimi, 32: 470-483.

Çetin, A. C. 2007. "Şirket derecelendirilmesinde faktör analizi kullanımı ve sektörlere yönelik Bir uygulama." Süleyman Demirel Üniversitesi İktisadi ve İdari Bilimler Fakültesi Dergisi, 12(3): 53-74.

Çoşkun, S. 2016. "Üniversite öğrencilerinin finansal davranış ve tutumlarının belirlenmesi: finansal okuryazarlık algıları üzerine bir araştırma." İnsan ve Toplum Bilimleri Araştırmaları Dergisi, 5(7): 2247-2258.

Denk, Z., Demir, Ö., \& Sezgin, E. E. 2018. "Kartlı ödeme sistemlerinin finansal davranış ve tutum üzerindeki etkisi: Elazığ-Malatya ili AVM müşterileri örneği." Fırat Üniversitesi Sosyal Bilimler Dergisi, 28(1): 187-202.

Er, B., \& Çetintaş, M. 2018). "İşçilerde finansal okuyazarlık: finansal bilgi, tutum ve davranış eksenli bir araştırma." Mersin Üniversitesi Sosyal Bilimler Enstitüsü e-dergi, 1(2): 61-71.

Falahati, L., Sabri, M. F., \& Paim, L. 2012. "Assessment a model of financial satisfaction predictors: examining the mddiate effect of financial behaviour and financial strain." World Applied Sciences Journal, 20(2): 190-197.

Field, A. 2009). Discovering statistics using SPSS (Third Edition ). California: SAGE Publications Inc.

Glasman, L. R., \& Dolores, A. 2006. "Forming attitudes that predict future behavior: A meta-analysis of the attitude-behavior relation." Psychological Bulletin, 132(5): 778-822.

Ibrahim, M. E., \& Alqaydi, F. R. 2013. "Financial literacy, personal financial attitude, and forms of personal debt among residents of the UAE." International Journal of Economics and Finance, 5(7): 126-138.

Jorgensen, B. L., Rappleyea, D. L., Schweichler, J. T., Fang, X., \& Moran, M. E. 2017. "The financial behavior of emerging adults: A family financial socialization approach." J Fam Econ, 38: 57-69.

Kayış, A. 2009. Güvenilirlik analizi (Reliability Analysis). Ş. Kalaycı içinde, SPSS uygulamalı çok değişkenli istatistik teknikleri (4. b., s. 403-419). Ankara: Asil Yayın Dağıtım.

Kirchmaier, I., Prüfer, J., \& Trautmann, S. T. 2018. "Religion, moral attitudes and economic behavior." Journal of Economic Behavior and Organization, 148: 282-300.

Kroesen, M., Handy, S., \& Chorus, C. 2017. "Do attitudes cause behavior or vice versa? An alternative conceptualization of the attitude-behavior relationship in travel behavior modeling." Transportation Research Part A, 101(7): 190-202.

Namlı, S., \& Kaya, A. 2018. Lisans öğrencilerinin finansal tutum ve davranışlarının ölçülmesi: Spor bilimleri fakültesi örneği. 3. Uluslararası El Ruha Sosyal Bilimler Kongresi, Şanlıurfa.

Özkalp, E., Varoğlu, A., Varoğlu, D., Kırel, A. Ç., \& Acar, P. 2013. Örgütsel davranış. Eskişehir: Anadolu Üniversitesi Yayınları.

Parrotta, J. L. 1996. The impact of financial attitudes and knowledge of financial management and satisfaction. The University of Bristish Columbia, A Master Thesis, Columbia.

Sarıgül, H. 2015. "Finansal okuryazarlık tutum ve davranış ölçeği: geliştirme, geçerlik ve güvenirlik." Yönetim ve Ekonomi Araştırmaları Dergisi, 13(1): 200-218.

Taştan, A., Kuşat, A., \& Çelik, C. 2001. "Üniversite düzeyinde din öğretimi alan öğrencilerde eğitim sürecinde oluşan tutum ve davranış değişiklikleri-Erciyes Üniversitesi İlahiyat Fakültesi örneği." Erciyes Üniversitesi Sosyal Bilimler Enstitüsü Dergisi, 1(11): 169-192.

Ünal, S., \& Düger, Y. S. 2015. "Akademik personelin finansal gönenç hâli ile finansal davranış eğilimi arasındaki ilişkiye yönelik ampirik bir araştırma." Bolu Abant İzzet Baysal Üniversitesi İktisadi ve İdari Bilimler Fakültesi Ekonomik ve Sosyal Araştırmalar Dergisi, 11(1): 213-226.

Yaşlığlu, M. M. 2017. "Sosyal bilimlerde faktör analizi ve geçerlilik: keşfedici ve doğrulayıcı faktör analizlerinin kullanılması." İstanbul Üniversitesi Işsletme Fakültesi Dergisi, 46(Özel Say1): 74-85.

Yong, C.C., Yew, S.Y., \& Wee, C.K. 2018. "Financial knowledge, attitude and behaviour of young working adults in Malaysia." Institutions and Economies, 10(4): 21-48. 
Day1, F., Esmer, Y. / Journal of Yasar University, 2021, 16/61, 1-19

YÖK. 2018. Yüksek Öğretim Bilgi Yönetim Sistemi- Öğretim Elemanı Sayıları Raporu, https://istatistik.yok.gov.tr/ (Erişim Tarihi: 12.12.2018). 